\title{
Mood stabilizer: a concept analysis and operationalization of a
}

\section{model}

Authors: Lauro Estivalete Marchionatti ${ }^{1}$, Paula Blaya-Rocha ${ }^{1}$, Pedro Vieira da Silva Magalhães ${ }^{1,2}$

Corresponding author: Pedro Vieira da Silva Magalhães - pmagalhaes@hcpa.edu.br

1. Laboratory of Molecular Psychiatry, Centro de Pesquisa Experimental (CPE) and Centro de Pesquisa Clínica (CPC), Hospital de Clínicas de Porto Alegre (HCPA), Porto Alegre, RS, Brazil.

2. Universidade Federal do Rio Grande do Sul, School of Medicine, Graduate Program in Psychiatry and Behavioral Sciences, Department of Psychiatry, Porto Alegre, RS, Brazil.

Acknowledgements: we thank Samanta Duarte Augusto for designing the graphical representations included in this paper.

Fundings: this study was funded by the Conselho Nacional de Desenvolvimento Cientifico e Tecnologico (CNPQq, Brazil. PVSM is supported by a National Council for Scientific and Technological Development - CNPq productivity fellowship.

Declarations of competing interests: the authors declare no potential conflicts of interest. 


\section{ABSTRACT}

Background. The term "mood stabilizer" is controversial in literature. As there is no consensual meaning, its retirement has been suggested to avoid confusion and misuse. On the other hand, it remains largely employed, and some advocate it carries an important meaning. This issue has not been previously approached using a validated qualitative inquiry.

Methods. We employed document analysis for reviewing proposed definitions for mood stabilizer. Then, we used concept analysis as a qualitative methodology to clarify meanings associated with the term. Based on its results, we built a theoretical model for mood stabilizer, matching it with evidence for drugs used in the treatment of bipolar disorder.

Results. Concept analysis of documents defining the term unearthed four attributes of a mood stabilizer that could be usefully nested into the following ascending hierarchy: "not worsening", "acute effects", "prophylactic effects", and "advanced effects". To be considered a mood stabilizer, a drug had to reach the "prophylactic effects" tier, as this was discussed by authors as the core aspect of the class. After arranging drugs according to this scheme, "lithium" and "quetiapine" received the label, but only the former fulfilled all four attributes, as evidence indicates it has neuroprotective action.

Conclusion. The proposed model uses a hierarchy of attributes that take into account the complexity of the term and help to determine whether a drug is a mood stabilizer. Prophylaxis is pivotal to the concept, whose utility lies in implying a drug able to truly treat bipolar disorder, as opposed to merely targeting symptoms. This could modify long-term outcomes and illness trajectory. 


\section{INTRODUCTION}

The moniker "mood stabilizer" appeared occasionally referring to lithium until the late 80s (Kerry and Owen 1970). While Schou (1963) had proposed that mood normalizers would "turn a pathologically changed mood into a normal one", the later notion of mood stabilization was more akin to prophylaxis and disease modification; stabilizing means "making unlikely to fail", a stabilizer "a thing used to make something steady or stable". With the incorporation of carbamazepine and valproate to the arsenal used to treat bipolar disorder and the new focus on prophylaxis, the "mood stabilizers" became a new class of psychotropics. In the 90s, the label gained popularity in the literature, being extended to antipsychotics (Zarate et al. 1995; Davis John M and Janicak Philip G 1996), with suggestions it was mainly chosen pragmatically by the pharmaceutical industry to imply new drugs were as effective as lithium (Healy 2008, chap. 6).

The utility of the term has been repeatedly questioned, as one that lacks clarity and is loosely employed (Safer 2010; Ghaemi 2001; G. M. Goodwin and Malhi 2007). Criticism revolves around the consequences of its imprecise meaning: since poorly defined, the term can be broadly (mis)understood (Malhi and Roy Chengappa 2017; Malhi, Porter, et al. 2018; Safer 2010). Consequently, medications can be labelled mood stabilizers after showing efficacy in specific domains of bipolar disorder (Malhi, Porter, et al. 2018). Once thus branded, its use is extended beyond the clinical domain its efficacy was demonstrated. This has been used as a further argument for retiring the term (Malhi and Roy Chengappa 2017; Safer 2010).

An analysis of trends of its use in titles of scientific papers does suggest a decline. From 1987 (its first recorded use in a title of a scientific paper), it has increased greatly until 2002, to then stabilize thereafter, a significantly different trajectory to the use of "bipolar disorder" (See 
medRxiv preprint doi: https://doi.org/10.1101/2021.11.13.21266303; this version posted November 16, 2021. The copyright holder for this preprint (which was not certified by peer review) is the author/funder, who has granted medRxiv a license to display the preprint in perpetuity.

It is made available under a CC-BY-NC-ND 4.0 International license .

Figure 1 and Figure 2 for comparison). Major professional guidelines still tend to employ the term liberally, although often disclaiming that the term ought to be employed more carefully and clearly. As an instance, the latest CANMAT guidelines state that its "use in the literature is inconsistent, and so [it] will not be used" (Yatham et al. 2018). Nevertheless, the term then appears another $\mathbf{2 2}$ times throughout the paper, and this is analogous to several professional guidelines (National Collaborating Centre for Mental Health (UK) 2018; Malhi, Outhred, et al. 2018).

This may suggest that the term "mood stabilizer" cannot easily be set aside, as it may still communicate some needed or intrinsic meaning. Perhaps, as Malhi et al. (2018) posit, it offers some hope and comfort to patients and clinicians. It indeed appears in many patient education pages, such as those of the National Health Service (14 March, 2019), National Institute for Health (2016) and UptoDate (Stovall 2021), to name a few. In the National Institute of Mental Health (NIMH) "resource for patients" webpage, it is informed that "mood stabilizers are used primarily to treat bipolar disorder [and] mood swings associated with other mental disorders" (“Mental Health Medications" n.d.).

The utility and destiny of this "class" of medications has certainly been long debated, most recently by Malhi and Chengappa (2017) in a series of thoughtful comments. While we see merit in arguments from both sides of the isle, some conceptual work could help in pointing to a more precise definition of what authors propose mood stabilizers should be. Here, we sought to define more clearly what has been meant by the "mood stabilizer" epithet and the consequences of this classification. We began by using document and concept analysis to delineate the necessary attributes of the term. While the usage of the term has been examined before, we are unaware of a formal exploration such as the one we provide here. Next, we propose a hierarchy 
medRxiv preprint doi: https://doi.org/10.1101/2021.11.13.21266303; this version posted November 16, 2021. The copyright holder for this preprint (which was not certified by peer review) is the author/funder, who has granted medRxiv a license to display the preprint in perpetuity.

It is made available under a CC-BY-NC-ND 4.0 International license .

of properties based on the categories we found. Finally, we made an attempt to operationalize these categories and, using the best available evidence, see where currently available treatments for bipolar disorder stand in this hierarchy.

\section{METHODS}

We employed document analysis as described by Bowen (2009) as the procedure for reviewing the material. The procedure entails finding, selecting, evaluating and synthesising the data contained in documents; the passages are then organized in themes and categories. We looked specifically for conceptual definitions through skimming, reading and discussing for the planned concept analysis. To be included, a document should specifically address and propose a clear definition of a "mood stabilizer". Thus, inclusions were mostly narrative reviews in which the authors could have used any number of rationales to come up with a definition of a mood stabilizer. The documents of interest were mostly published articles, but we also included books addressing the issue when referenced. We undertook searches in Medline, Scopus and PsychInfo with the terms "mood stabiliz*", "mood stabilis*", "mood normaliz", without constraints on time of publication or language. While not systematically reviewing everything written on mood stabilizers, we sought to include recognized proposals and reference guidelines and inspected reference lists on those for additional definitions. As such, we excluded from the concept analyses those pieces that only review or criticize the term (for instance, see Sobo (1999), Keck and McElroy (2003), and López-Muñoz et al. (2018)), although we addressed some of these in the discussion. Document analysis does not rely on completeness, but on a wide array of documents, prioritising quality over comprehensiveness. 
medRxiv preprint doi: https://doi.org/10.1101/2021.11.13.21266303; this version posted November 16, 2021. The copyright holder for this preprint (which was not certified by peer review) is the author/funder, who has granted medRxiv a license to display the preprint in perpetuity.

It is made available under a CC-BY-NC-ND 4.0 International license .

\section{Concept analysis}

Concept analysis is a qualitative methodology that has been developed as a method of clarification and characterization of phenomena that can isolate defined and irrelevant attributes of a concept. Once a more concrete perspective is reached, it serves as a firmer starting point to guide research and exploration (Foley and Davis 2017).

There are several approaches to conducting a concept analysis (Walker 2005; Morse 1995; Wilson 1963). We employ evolutionary concept analysis as described by Rodgers and Knalf (1993), which presents a clear analytic framework, with strengths on its systematization, divided into well established phases. It takes into account how a concept evolves over time, considering it a dynamic process wherein the context is central, thus accounting for shifts in evolving concepts, adding a temporal perspective. A concept analysis consists of identification of a concept of interest including surrogate terms, a setting for sample selection, collection of data relevant to attributes of the concept, contextual basis of the concept that is inclusive of antecedents and consequences as well as interdisciplinary and sociocultural variations, analysis of data according to these characteristics, identification of an exemplar, and implications for further development of the concept. Each piece was read several times until the general theme was identified; analysis proceeded using phrases as units of analysis.

\section{Operationalization for efficacy analysis}

As a next step (Figure 5), we sought to operationalize the categories obtained from the content analysis and look for the best evidence in the extant efficacy literature for drug effects in bipolar disorder, following Bauer and Mitchner (2004). 
medRxiv preprint doi: https://doi.org/10.1101/2021.11.13.21266303; this version posted November 16, 2021. The copyright holder for this preprint (which was not certified by peer review) is the author/funder, who has granted medRxiv a license to display the preprint in perpetuity.

It is made available under a CC-BY-NC-ND 4.0 International license .

We opted to start operationalizing treatment response per phase (acute vs maintenance) and polarity (manic/mixed vs depressed). We are aware, as Malhi et al. (2018) notes, that other dimensions such as activation are involved as well, but this is clearly how authors tend to conceptualize response and how studies are conducted. Whenever possible, we drew on network meta-analysis of monotherapy trials as the most comprehensive and simplest methodology to determine efficacy in such phases, following evidence hierarchy (Roever and Biondi-Zoccai 2016). This supplied data referring to the treatment of acute depression (Bahji et al. 2020a), acute mania (Yildiz et al. 2015), and maintenance treatment (Miura et al. 2014). However, randomized placebo controlled studies concerning long-term data are sparse and usually restricted to relapse rates, providing very limited information. In these cases, we looked further into the naturalistic hospitalization data. While many such reports understandably use lithium as a relevant comparison (Kessing et al. 2018), and many reveal advantages for lithium, more pertinent to our objectives were studies that employed an on-off design, with the same individual being compared at different points of time, thus testing the hypothesis of a benefit or harm of different medications. Joas et al. (2017) tested a number of drugs in Swedish registries considering their benefits on preventing hospitalizations, while Lähteenvuo et al. (2018) included an assessment of detrimental effects using rehospitalization data from the Finnish population.

The "not worsening" category was operationalized considering both short-term and longterm outcomes. Short-term "not worsening" was informed by network meta-analyses of acute mania and bipolar depression, wherein a drug could not display propensity to cause acute manic or depressive switches as being inferior to placebo. As for long-term data, while the network meta analysis on maintenance treatment was taken into account, we further examined evidence for harm of medication by looking at the observational on/off design by Lähteenvuo et al. (2018), 
which indicated whether adding a drug into a regimen increases odds of rehospitalization. Drugs with evidence of harm were classified as "mood destabilizers", and therefore placed out of the hierarchy rank, regardless of possible benefits on subsequent categories.

As for "acute effects", we used data from most recently available network meta-analyses to investigate superiority to placebo in monotherapy in acute mania (Yildiz et al. 2015) or bipolar depression (Bahji et al. 2020b), discarding those drugs previously shown to worsen outcomes. This category only concerns short-term treatment and thus was not supplemented by additional observational studies.

To determine "prophylactic effects", we started from data provided by network metaanalysis to show superiority in monotherapy to placebo in terms of relapses to mania, depression or either (Miura et al. 2014). This category was also informed by available on/off hospitalization data based on national registries to gauge prophylactic effects on hospitalizations for mood episodes of each polarity, as informed by Joas et al. (2017). To qualify for the rank, a drug had to display efficacy on preventing any episodes of either mania or depression..

The "advanced effects" category concerns cognition and quality of life, proving a much more difficult dimension to operationalize in terms of direct comparisons and generalizability. Instead of summing up the evidence, we limited ourselves to discussing this notion considering studies possibly signaling neuroprotective effects, as this is a feasible proxy to evaluate such outcomes. 


\section{RESULTS}

\section{Concept analysis}

We located 8 relevant articles for our document analysis. To be included, there should be a clear proposal on the meaning of a "mood stabilizer". The first relevant conceptual proposal was published in 1996 and the most recent in 2018 (Figure 3). We identified four nonoverlapping attributes in the definition of a mood stabilizer (Figure 4).

\section{Not worsening}

Authors agree that mood stabilizers should not have deleterious effects on current or subsequent mood episodes. This was elaborated on in several passages. Sachs (1996) proposes that a mood stabilizer "does not exacerbate the current acute episode". He gives examples of medications that would be excluded by this rule: "available antidepressant medications may precipitate mania or worsen the course of illness [...] and chronic use of antipsychotics appears to increase the risk of recurrent depression". Bowden (1998) states that a mood stabilizer "does not increase frequency or severity of any of the types of bipolar disorder episodes". There are clear consequences to including this category, as a drug could be beneficial in one phase, such as acute depression or mania, whilst causing affective switches or worsening long-term outcomes. Drugs that have the potential of being harmful have usually been termed "mood destabilizers" in the literature.

\section{Acute effects}

Authors also discuss what beneficial effects a mood stabilizer should have on the treatment of acute mood episodes. Calabrese and Rapport (1999) suggest that these drugs are "effective as monotherapy for the acute treatment of depression (and mania and mixed states)", 
medRxiv preprint doi: https://doi.org/10.1101/2021.11.13.21266303; this version posted November 16, 2021. The copyright holder for this preprint (which was not certified by peer review) is the author/funder, who has granted medRxiv a license to display the preprint in perpetuity.

It is made available under a CC-BY-NC-ND 4.0 International license .

similarly to Bauer and Mitchner's (2004) proposal that include "the treatment of acute manic symptoms" and "the treatment of acute depressive symptoms". This common attribute we named "acute effects".

\section{Prophylactic effects}

It is debated how this class should reduce either the occurrence, the frequency or the severity of new episodes. Sachs (1996) defends that these drugs "could be defined as a treatment that decreased the vulnerability to subsequent episodes of mania or depression", whilst Malhi and Chengappa (2017) argue "that it must achieve sustained long-term functional mood stability and discernibly prevent future illness". We grouped these notions under a category we named "prophylactic effects".

Relapse prevention is also discussed as a sine qua non condition of including a drug in the mood stabilizer category. For instance, Goodwin and Jamison (2007) state that "a prophylactic efficacy should be fundamental to the definition of a mood stabilizer, and that including drugs in this category simply on the basis of acute efficacy against depression and or mania renders the term so broad as to be essentially meaningless". Medications with prophylactic effects are also described by Keck and McElroy (2003) as addressing "the core trait of bipolar disorder, its cyclic nature and propensity for recurrence". They also state that "maintenance treatment of bipolar disorder is perhaps its most important aspect". Sachs (1996) also emphasizes the primacy of prophylaxis when writing that these treatments would "result in a decreased risk of cycling whether or not they possess acute antimanic or antidepressant effects".

\section{Advanced effects}

Finally, authors also debate further effects a mood stabilizer would have beyond the previous categories. They were first mentioned by Keck and McElroy (2003). When summarizing 
medRxiv preprint doi: https://doi.org/10.1101/2021.11.13.21266303; this version posted November 16, 2021. The copyright holder for this preprint (which was not certified by peer review) is the author/funder, who has granted medRxiv a license to display the preprint in perpetuity.

It is made available under a CC-BY-NC-ND 4.0 International license .

uses of the term mood stabilizer, he includes "comprehensive definitions" that deal with symptoms related to cognition and behavior. It was Malhi et al. (2018) who formally proposed such an attribute as part of a mood stabilizer, fleshing out that "subjective quality of life, tolerability, and effects on cognition and activity also need to be considered when determining whether a medication is a potential mood stabiliser". These effects, wherein we suggest neuroprotective action should be included, were grouped under our fourth category and named "advanced effects".

\section{A hierarchy of mood stabilizing drugs}

The manner in which many authors define a mood stabilizer revealed several attributes of this class that should be taken into account when constructing a model for the concept. Individually discussing the attributes would be insufficient, as they were clearly interrelated. Some attributes were more refined and considered essential to qualify a drug as a mood stabilizer, whilst others did not guarantee the label by themselves, yet presenting therapeutic benefits. Therefore, we propose here a hierarchy of progressively specific properties that embraces the complexity of the treatment of bipolar disorder and could help understanding whether a drug has mood stabilizing properties.

We thus suggest the members of the categories above could be ordered in progressive ranks (Figure 4). Our first category of "not worsening any episode" seems to be cardinal to define a base: without fulfilling this precondition, a drug cannot be labelled a mood stabilizer. This tier holds place for drugs not showing either benefit nor harm in the management of bipolar disorder. Some compounds could be placed below this level, and would conceptually be outside of the hierarchy of drugs used to treat bipolar disorder. Those have usually been called "mood 
medRxiv preprint doi: https://doi.org/10.1101/2021.11.13.21266303; this version posted November 16, 2021. The copyright holder for this preprint (which was not certified by peer review) is the author/funder, who has granted medRxiv a license to display the preprint in perpetuity.

It is made available under a CC-BY-NC-ND 4.0 International license .

destabilizers", where evidence indicates they can worsen the course of bipolar disorder or cause affective switches. The next tier holds place for drugs that have no evidence of being harmful and have relevant acute effects, either for mania or bipolar depression. While not conceptualized as mood stabilizers yet, they could still be useful for managing acute episodes.

The following higher tier would consist of actual mood stabilizers, that is, drugs that would not be harmful for any phase, be useful acutely in either mania or bipolar depression and possess prophylactic efficacy for preventing mood episodes of both polarities. Finally, the apex of the pyramid would be reserved to those members that have desirable additional properties to that of a conventional mood stabilizer. These advanced effects could be understood as evidence that the drug has some fundamental ability to change the course of the illness for the better, perhaps halting neuroprogressive changes and thus preserving functioning and cognition.

\section{Current drugs used in the treatment of bipolar disorder}

Finally, we gathered and organized the evidence on the effects of drugs currently used to treat bipolar disorder based on this proposed hierarchy. To that end, we found several network meta-analyses that are useful in understanding treatment effects (for acute depression, acute mania or prophylaxis) (Bahji et al. 2020a; Yildiz et al. 2015; Miura et al. 2014). Those were generally unhelpful at detecting effects on the longer-run illness course, thus being complemented with observational data (Joas et al. 2017; Lähteenvuo et al. 2018). Table 1 and Table 2 presents pertinent findings from these studies, and Figure 6 displays how drugs were allocated in our hierarchy.

Mood destabilizers demonstrably worsen any phase or the general illness course, but network meta-analyses on maintenance treatment and on acute effects for mania or bipolar 
medRxiv preprint doi: https://doi.org/10.1101/2021.11.13.21266303; this version posted November 16, 2021. The copyright holder for this preprint (which was not certified by peer review) is the author/funder, who has granted medRxiv a license to display the preprint in perpetuity.

It is made available under a CC-BY-NC-ND 4.0 International license .

depression did not reveal any substance significantly worse than placebo on causing manic or depressive switches. The observational on/off literature, though, suggested hospitalization is more common during periods on any antidepressant or benzodiazepine. These drugs were placed below the "not worsening" tier, being disqualified to occupy other ranks in the hierarchy of mood stabilizer regardless of showing acute benefits. The not worsening category was left for drugs that did not display any evidence of harm, but also did not prove useful when evaluated for acute or maintenance effects. These were gabapentin, oxcarbazepine, licarbazepine, and verapamil.

Many drugs have meaningful acute effects, especially for mania. These include several atypical antipsychotics, haloperidol, carbamazepine, valproate, and lithium. For bipolar depression there are fewer drugs with randomized evidence of efficacy: four atypical antipsychotics (lurasidone, quetiapine, cariprazine, olanzapine), valproate, and lamotrigine. All these drugs are seated in the "acute effects" tier. While some antidepressants were of benefit in treating acute depressive symptoms, they did not qualify to this rank for previously showing evidence of being mood destabilizers.

A subgroup of drugs with acute effects also showed evidence of efficacy for the prevention of episodes. Lithium, valproate, lamotrigine, quetiapine, risperidone and olanzapine were superior to placebo in preventing relapse of either mania or depression, but only lithium and quetiapine proved efficacious for preventing episodes of both polarities. The observational data by Joas et al. (2017) supported four drugs on preventing hospitalizations for both manic and depressive episodes: lithium, valproate, quetiapine, olanzapine, also noting that effect size of lithium was significantly superior to all others except valproate. As the medications that proved efficacious on both study designs and for both polarities, quetiapine and lithium qualified to the 
medRxiv preprint doi: https://doi.org/10.1101/2021.11.13.21266303; this version posted November 16, 2021. The copyright holder for this preprint (which was not certified by peer review) is the author/funder, who has granted medRxiv a license to display the preprint in perpetuity.

It is made available under a CC-BY-NC-ND 4.0 International license .

higher place of "prophylactic effects" in the hierarchy, being finally labelled "mood stabilizers". To note, all drugs surpassing the "prophylactic effects" category had fulfilled the previous category of "acute effects".

As for advanced effects, we considered these properties are still not consolidated and warrant further investigation. Therefore we limited ourselves to point to studies possibly signaling their presence. Interestingly, they all refer to lithium. Perhaps the best evidence is presented in a randomized clinical trial comparing effects of quetiapine and lithium on white and grey matter volume after a first episode of mania in a 12-month follow-up of 26 patients and 20 healthy controls (Berk et al. 2017). Assessed by structural magnetic resonance, gray and white matter volumes were reduced in patients after a single episode of mania, but not in control individuals. After 12 months, this loss was more pronounced in patients using quetiapine, signaling possible neuroprotective effects of lithium. These effects are corroborated by observational data, at least for lithium excellent responders showing preserved cognitive function (Rybakowski and Suwalska 2010).

\section{DISCUSSION}

The term "mood stabilizer" is increasingly employed with skepticism of its utility and a growing dissension as to its meaning. We approached this issue by conducting a concept analysis of proposed definitions for the term, which unveiled four main attributes of a mood stabilizer. To embrace the distinct relevance ascribed to each one, they were integrated into a hierarchical scheme of the following crescendo ranks: "not worsening", "acute effects", "prophylactic effects", and "advanced effects". As authors discussed prophylactic effects as a core aspect of a mood stabilizer, only drugs surpassing this tier of the hierarchy would be crowned the label. 
medRxiv preprint doi: https://doi.org/10.1101/2021.11.13.21266303; this version posted November 16, 2021. The copyright holder for this preprint (which was not certified by peer review) is the author/funder, who has granted medRxiv a license to display the preprint in perpetuity.

It is made available under a CC-BY-NC-ND 4.0 International license .

Then, using the best available evidence, we tentatively arranged widely available drugs according to such a hierarchy. This reinforced the suitability of the scheme, as many drugs could be placed in the first tiers, which progressively narrowed down as more refined attributes were required. Only lithium and quetiapine fulfilled requisites to be considered mood stabilizers, with lithium showing quite superior prophylactic efficacy in real-world data and being the sole drug for which studies signaled advanced effects in preserving cognition.

The concept of a mood stabilizer drug has been discussed before, although not using a formal document analysis such as this one. There is continuous debate on what really is a mood stabilizer and proposals for definitions come up every now and then (Sachs 1996; Calabrese and Rapport 1999; Bowden 1998; Ghaemi 2001; F. K. Goodwin and Jamison 2007; Malhi, Porter, et al. 2018). Some authors also attempted to summarize what the current ideas of a mood stabilizer were, without proposing a different one (Keck and McElroy 2003; López-Muñoz et al. 2018). They grouped the definitions under categories, which were named "lithium-inspired", "uniphasic", "comprehensive" "conservative" and "broader" definitions. Harris et al. (2003) analyzed the historical development of the term: its roots were traced back to the time Schou (1963) noted lithium had prophylactic effects on manic-depressive episodes, evolved with anticonvulsants emergence as first-line treatments to the disorder, being then linked to Post et al.'s (1982) formulation of the kindling model of manic-depressive episodes. For its turn, Bauer and Mitchner (2004) worked on matching the evidence of drug effectiveness with a proposed $4 \times 4$ definition of mood stabilizer, being lithium the sole drug able to treat and prevent both manic and depressive episodes.

There is also some criticism surrounding the term. A good debate is found in a paper by Malhi and Chengappa (2017). The first author analyzes how the term is poorly-defined, resulting 
medRxiv preprint doi: https://doi.org/10.1101/2021.11.13.21266303; this version posted November 16, 2021. The copyright holder for this preprint (which was not certified by peer review) is the author/funder, who has granted medRxiv a license to display the preprint in perpetuity.

It is made available under a CC-BY-NC-ND 4.0 International license .

in many drugs receiving the label after demonstrating effectiveness in a single aspect of disease. He argues that an appealing term in a context of loose definitions amplifies the prescription of such drugs beyond the limits of their efficacy. Chengappa draws on similar arguments to label the term mood stabilizer misleading and support its retirement, instead labeling drugs simply "antimanic or antidepressant agents for bipolar disorder". Notwithstanding, Malhi argues for keeping the term and suggests a starting point for a definition on a drug that "achieve sustained long-term functional mood stability and discernibly prevent future illness". Another argument for abandoning the term is the lack of a consensual definition (López-Muñoz et al. 2018; Safer 2010). Indeed, this imprecision is an issue with its consequences, as one could argue of Bowden (1998), who branded lamotrigine and valproate as mood stabilizer to sponsor such drugs. Nevertheless, the imprecision is a barrier to be overcome through a better understanding of a mood stabilizer. We approached this matter using the concept analysis methodology, what made the term clearer in its meanings and unveiled its utility.

The concept of a mood stabilizer is certainly a complex one, as revealed in the definitions proposed. Authors are not satisfied in proposing a single action as the key property of a mood stabilizer, and such drug is expected to have multiple effects in distinct areas of bipolar disorder. The complexity comes from the very nature of bipolar disorder, as a disorder with multiple and quite distinct manifestations. That is mirrored in proposals to define mood stabilizer such as the one by Malhi et al. (2018), wherein a $4 \times 4$ graph is built to quantify how effective a drug is in the prevention and acute treatment of each pole of disease, disregarding how they work in combination or what the core properties are. Nevertheless, it is precisely in dealing with this complexity that lies the value of the concept of a mood stabilizer, and an argument to keep the term in psychiatric lexicon: it implies a drug able to bring therapeutic effects for bipolar disorder, 
medRxiv preprint doi: https://doi.org/10.1101/2021.11.13.21266303; this version posted November 16, 2021. The copyright holder for this preprint (which was not certified by peer review) is the author/funder, who has granted medRxiv a license to display the preprint in perpetuity.

It is made available under a CC-BY-NC-ND 4.0 International license .

as opposed to merely targeting symptoms or specific phases of disease. Somehow related to it is the idea of "normothymotics" or "mood normalizer", brought by Schou (1963) and "representing a class of drugs with an action specific to a disease rather than a symptom or syndrome". This may have clear consequences for both research and clinical practice: such a drug would result in a simplified prescription and better outcomes in the long-run. Indeed, prophylaxis is broadly argued as a core quality of a mood stabilizer.

Emphasizing the long-term outcomes as opposed to short term symptomatic treatment of bipolar disorder is vital because of its potential to be disease-modifying. Not only do mood episodes directly bring biological, psychological and psychosocial deleterious effects for patients, but also increase the vulnerability to new episodes (Park et al. 2018). Many patients have a progressive course of disease, and there is a robust body of literature on neuroprogression and on staging bipolar disorder focused on impaired cognition and functioning (Robert M. Post, Fleming, and Kapczinski 2012). As for truly treating bipolar disorder, a mood stabilizer could preclude this neuroprogression, being a disease-modifying therapy. In fact, our analysis captured an additional category we termed "advanced effects", which relates to the preservation of cognition and quality of life. While this could not be systematically tested and should be critically looked at, some clinical studies point to lithium as having particular neuroprotective properties (Berk et al. 2017). Indeed, the case of lithium excellent responders may stand as a real-life example of the concept of mood stabilizer: they are defined as patients for whom monotherapy lithium fully prevents further mood episodes for an extended period of time, achieving long-term remission, also with some observational data indicating protective effects on cognitive functions (Rybakowski and Suwalska 2010). 
medRxiv preprint doi: https://doi.org/10.1101/2021.11.13.21266303; this version posted November 16, 2021. The copyright holder for this preprint (which was not certified by peer review) is the author/funder, who has granted medRxiv a license to display the preprint in perpetuity.

It is made available under a CC-BY-NC-ND 4.0 International license .

Achieving remission on monotherapy is a fact to be noted, and another argument for a mood stabilizer. A medication truly treating bipolar disorder diminishes the need of employing a multiplicity of drugs, each targeting some symptom or phases of the disease. This is a well desired goal, as polypharmacy stands for the rule in the treatment of bipolar disorder (Kim, Salstein, and Goldberg 2021; Grover et al. 2021), an approach not devoid of risks: it difficults adherence and tolerability, burden up side effects, increases costs and is often misleading, to name a few (V. C. Fung et al. 2019; V. Fung et al. 2013).

A major strength of this study was applying a qualitative inquiry of validated methodologies when approaching the concept of mood stabilizer. We could construct a hierarchy embracing these attributes, as well as establish the primacy of prophylactic effects, further relating it to a potential to be disease-modifying. In this sense, lithium-excellent responders could represent real-world instances of mood stabilization. Indeed, this drug was among the two fulfilling requisites to be named mood stabilizer according to our hierarchy, showing significant superior efficacy to others in prophylactic effects according to long-term observational data. Moreover, it is the only compound for which the highest tier of advanced effects was suggested, as clinical evidence indicates it could preserve cognition.

This study is not without limitations. Some categories were based on the perspectives of only a few authors. Many definitions were not richly described or examined, also limiting conceptual analysis. Additionally, studies are often not abundant and also present limitations, which are reflected on our results. Studies for acute effects were easier to find and provided solid answers concerning antimanic and antidepressant effects. However, researching maintenance/prophylactic effects require long-term studies, which are more dispendious to conduct. We used maintenance meta analysis which included studies from 17 weeks to 2.5 years 
medRxiv preprint doi: https://doi.org/10.1101/2021.11.13.21266303; this version posted November 16, 2021. The copyright holder for this preprint (which was not certified by peer review) is the author/funder, who has granted medRxiv a license to display the preprint in perpetuity.

It is made available under a CC-BY-NC-ND 4.0 International license .

of durations, which is probably shorter than we wished for definitive answers. Therefore, we supplemented it with data from on/off naturalistic studies. This method could have introduced some inherent biases of observational data, including significant interpretation challenges because of intense polypharmacy.

Moreover, the advanced effects represented a major challenge to operationalize and could not be tested with confidence. Available literature only provided clues regarding effects on cognition, mostly through an intermediate outcome of neuroprotective action. In the case of quality of life, this category could not be operationalised, as no study succeeded in establishing which drugs are associated with benefits on such outcomes. Thus, this category of our mood stabilizer concept was left unclosed, undermining its utility for a clinical scope.

In conclusion, a qualitative inquiry shed light on the controversial term of concept analysis, indicating it has a meaning not to abandon. While multiple attributes are expected from such a drug, they should be looked at conjunctly, having prophylaxis as a determinant aspect. We nested these attributes into the following crescendo ranks: "not worsening", "acute effects", "prophylactic effects", and "advanced effects", with "prophylactic effects" standing as the dividing line from which a drug can be considered a mood stabilizer. This aggregation was reinforced by quantitative evidence, as effectiveness from drugs also narrowed down according to the hierarchy. According to such, only lithium and quetiapine could be labeled mood stabilizers, with "advanced effects" being suggested for lithium. This conceptualization fleshes out the utility of the term mood stabilizer: it implies a drug able to truly treat bipolar disorder, which could redeem better outcomes in the long-run, being potentially disease-modifying. Lithium-excellent responders may stand as a real-world example of that. 


\section{REFERENCES}

Bahji, Anees, Dylan Ermacora, Callum Stephenson, Emily R. Hawken, and Gustavo Vazquez. 2020a. "Comparative Efficacy and Tolerability of Pharmacological Treatments for the Treatment of Acute Bipolar Depression: A Systematic Review and Network Meta-Analysis." Journal of Affective Disorders 269 (May): 154-84.

- - . 2020b. "Comparative Efficacy and Tolerability of Pharmacological Treatments for the Treatment of Acute Bipolar Depression: A Systematic Review and Network Meta-Analysis." Journal of Affective Disorders 269 (May): 154-84.

Bauer, Mark S., and Landis Mitchner. 2004. "What Is a 'Mood Stabilizer'? An Evidence-Based Response." American Journal of Psychiatry 161 (1): 3-18.

Berk, Michael, O. Dandash, R. Daglas, S. M. Cotton, K. Allott, Alex Fornito, C. Suo, et al. 2017. "Neuroprotection after a First Episode of Mania: A Randomized Controlled Maintenance Trial Comparing the Effects of Lithium and Quetiapine on Grey and White Matter Volume." Translational Psychiatry 7 (1): e1011-e1011.

Bowden, C. L. 1998. "New Concepts in Mood Stabilization: Evidence for the Effectiveness of Valproate and Lamotrigine." Neuropsychopharmacology: Official Publication of the American College of Neuropsychopharmacology 19 (3): 194-99.

Bowen, Glenn A. 2009. "Document Analysis as a Qualitative Research Method." Qualitative Research Journal 39 (August): 88.

Calabrese, J. R., and D. J. Rapport. 1999. "Mood Stabilizers and the Evolution of Maintenance Study Designs in Bipolar I Disorder." The Journal of Clinical Psychiatry 60 Suppl 5: 5-13; discussion 14-15.

Davis John M, and Janicak Philip G. 1996. “Risperidone: A New, Novel (and Better?) Antipsychotic." Psychiatric Annals 26 (2): 78-87.

Foley, Angela S., and Alison H. Davis. 2017. "A Guide to Concept Analysis." Clinical Nurse Specialist CNS 31 (2): 70-73.

Fung, Vicki C., Lindsay N. Overhage, Louisa G. Sylvia, Noreen A. Reilly-Harrington, Masoud Kamali, Keming Gao, Richard C. Shelton, et al. 2019. "Complex Polypharmacy in Bipolar Disorder: Side Effect Burden, Adherence, and Response Predictors." Journal of Affective Disorders 257 (October): 17-22.

Fung, Vicki, Mary Price, Alisa B. Busch, Mary Beth Landrum, Bruce Fireman, Andrew Nierenberg, William H. Dow, et al. 2013. "Adverse Clinical Events among Medicare Beneficiaries Using Antipsychotic Drugs: Linking Health Insurance Benefits and Clinical Needs." Medical Care 51 (7): 614-21.

Ghaemi, S. N. 2001. “On Defining 'Mood Stabilizer.”' Bipolar Disorders 3 (3): 154-58.

Goodwin, Frederick K., and Kay Redfield Jamison. 2007. Manic-Depressive IIIness: Bipolar Disorders and Recurrent Depression. Oxford University Press, USA.

Goodwin, Guy M., and Gin S. Malhi. 2007. "What Is a Mood Stabilizer?" Psychological Medicine 37 (5): 609-14.

Grover, Sandeep, Ajit Avasthi, Rahul Chakravarty, Amitava Dan, Kaustav Chakraborty, Rajarshi Neogi, Avinash Desouza, et al. 2021. "Prescription Patterns in Clinically Stable Patients with Bipolar Disorder: Findings from the Bipolar Disorder Course and Outcome from India (BiDColN) Study." Asian Journal of Psychiatry 57 (March): 102549. 
Harris, Margaret, Summit Chandran, Nabonita Chakraborty, and David Healy. 2003. "MoodStabilizers: The Archeology of the Concept." Bipolar Disorders 5 (6): 446-52.

Healy, David. 2008. "Mania: A Short History of Bipolar Disorder." Johns Hopkins Biographies of Disease. 296. https://psycnet.apa.org/fulltext/2008-00874-000.pdf.

Joas, Erik, Alina Karanti, Jie Song, Guy M. Goodwin, Paul Lichtenstein, and Mikael Landén. 2017. "Pharmacological Treatment and Risk of Psychiatric Hospital Admission in Bipolar Disorder." The British Journal of Psychiatry: The Journal of Mental Science 210 (3): 197-202.

Keck, Paul E., Jr, and Susan L. McElroy. 2003. "Redefining Mood Stabilization." Journal of Affective Disorders 73 (1-2): 163-69.

Kerry, R. J., and G. Owen. 1970. “Lithium Carbonate as a Mood and Total Body Water Stabilizer.” Archives of General Psychiatry 22 (4): 301-3.

Kessing, Lars Vedel, Michael Bauer, Willem A. Nolen, Emanuel Severus, Guy M. Goodwin, and John Geddes. 2018. "Effectiveness of Maintenance Therapy of Lithium vs Other Mood Stabilizers in Monotherapy and in Combinations: A Systematic Review of Evidence from Observational Studies." Bipolar Disorders 20 (5): 419-31.

Kim, Anna M., Lisa Salstein, and Joseph F. Goldberg. 2021. "A Systematic Review of Complex Polypharmacy in Bipolar Disorder: Prevalence, Clinical Features, Adherence, and Preliminary Recommendations for Practitioners." The Journal of Clinical Psychiatry 82 (3). https://doi.org/10.4088/JCP.20r13263.

Lähteenvuo, Markku, Antti Tanskanen, Heidi Taipale, Fabian Hoti, Pia Vattulainen, Eduard Vieta, and Jari Tiihonen. 2018. "Real-World Effectiveness of Pharmacologic Treatments for the Prevention of Rehospitalization in a Finnish Nationwide Cohort of Patients With Bipolar Disorder." JAMA Psychiatry 75 (4): 347-55.

López-Muñoz, Francisco, Winston W. Shen, Pilar D'Ocon, Alejandro Romero, and Cecilio Álamo. 2018. "A History of the Pharmacological Treatment of Bipolar Disorder." International Journal of Molecular Sciences 19 (7). https://doi.org/10.3390/ijms19072143.

Malhi, Gin S., Tim Outhred, Grace Morris, Philip M. Boyce, Richard Bryant, Paul B. Fitzgerald, Malcolm J. Hopwood, et al. 2018. "Royal Australian and New Zealand College of Psychiatrists Clinical Practice Guidelines for Mood Disorders: Bipolar Disorder Summary." The Medical Journal of Australia 208 (5): 219-25.

Malhi, Gin S., Richard Porter, Lauren Irwin, Amber Hamilton, Grace Morris, Darryl Bassett, Bernhard T. Baune, et al. 2018. "Defining a Mood Stabiliser: Novel Framework for Research and Clinical Practice." BJPsych Open 4 (4): 278-81.

Malhi, Gin S., and K. N. Roy Chengappa. 2017. "Why ‘mood Stabilizer’ Needs Stability: Polar Views on Its Utility." Bipolar Disorders. https://doi.org/10.1111/bdi.12562.

"Mental Health Medications." n.d. Accessed July 10, 2021. https://www.nimh.nih.gov/health/topics/mental-health-medications/.

Miura, Tomofumi, Hisashi Noma, Toshi A. Furukawa, Hiroshi Mitsuyasu, Shiro Tanaka, Sarah Stockton, Georgia Salanti, et al. 2014. "Comparative Efficacy and Tolerability of Pharmacological Treatments in the Maintenance Treatment of Bipolar Disorder: A Systematic Review and Network Meta-Analysis." The Lancet. Psychiatry 1 (5): 351-59.

Morse, J. M. 1995. "Exploring the Theoretical Basis of Nursing Using Advanced Techniques of Concept Analysis." ANS. Advances in Nursing Science 17 (3): 31-46.

National Collaborating Centre for Mental Health (UK). 2018. Bipolar Disorder: The NICE Guideline on the Assessment and Management of Bipolar Disorder in Adults, Children and Young 
People in Primary and Secondary Care. London: The British Psychological Society and The Royal College of Psychiatrists.

National Health Service. 14 March, 2019. "Overview - Bipolar Disorder." National Health Service. 14 March, 2019. https://www.nhs.uk/mental-health/conditions/bipolar-disorder/overview/. National Institute of Mental Health. 2016. "Mental Health Medications." National Institute of Mental Health. October 2016. https://www.nimh.nih.gov/health/topics/mental-healthmedications/.

Park, Dong Yeon, Dennis Do, Lauren Chang, Saloni Shah, Laura D. Yuen, Farnaz Hooshmand, Po W. Wang, Shefali Miller, and Terence A. Ketter. 2018. "Episode Accumulation Associated with Hastened Recurrence and Delayed Recovery in Bipolar Disorder." Journal of Affective Disorders 227 (February): 657-64.

Post, R. M., T. W. Uhde, F. W. Putnam, J. C. Ballenger, and W. H. Berrettini. 1982. "Kindling and Carbamazepine in Affective Illness." The Journal of Nervous and Mental Disease 170 (12): 717-31.

Post, Robert M., Jaclyn Fleming, and Flavio Kapczinski. 2012. "Neurobiological Correlates of Illness Progression in the Recurrent Affective Disorders." Journal of Psychiatric Research 46 (5): 561-73.

Rodgers, Beth L., and Kathleen Astin Knafl. 1993. "Concept Analysis. An Evolutionary View." In Concept Development in Nursing: Foundations, Techniques, and Applications, edited by Beth L. Rodgers and Kathleen Astin Knafl, 77-102. W-B Saunders Company.

Roever, Leonardo, and Giuseppe Biondi-Zoccai. 2016. "Network Meta-Analysis to Synthesize Evidence for Decision Making in Cardiovascular Research." Arquivos Brasileiros de Cardiologia 106 (4): 333-37.

Rybakowski, Janusz K., and Aleksandra Suwalska. 2010. "Excellent Lithium Responders Have Normal Cognitive Functions and Plasma BDNF Levels." The International Journal of Neuropsychopharmacology / Official Scientific Journal of the Collegium Internationale Neuropsychopharmacologicum 13 (5): 617-22.

Sachs, G. S. 1996. "Bipolar Mood Disorder: Practical Strategies for Acute and Maintenance Phase Treatment." Journal of Clinical Psychopharmacology 16 (2 Suppl 1): 32S - 47S.

Safer, Daniel J. 2010. "Mood Swing and Mood Stabilizer: How Specific Are These Terms?" Bipolar Disorders 12 (7): 685-90.

Schou, Mogens. 1963. "Normothymotics, 'Mood-Normalizers': Are Lithium and the Imipramine Drugs Specific for Affective Disorders?” The British Journal of Psychiatry: The Journal of Mental Science 109 (463): 803-9.

Sobo, Simon. 1999. "Mood Stabilizers and Mood Swings: In Search of a Definition." The Psychiatric Times 16 (10): 36-42.

Stovall, Jeffrey. 2021. "Patient Education: Bipolar Disorder (manic Depression) (Beyond the Basics)." UptoDate. June 17, 2021. https://www.uptodate.com/contents/bipolar-disordermanic-depression-beyond-the-basics.

Walker, Lorraine Olszewski. 2005. "Strategies for Theory Construction in Nursing." catalogue.pearsoned.ca. 2005. http://catalogue.pearsoned.ca/assets/hip/ca/hip_ca_pearsonhighered/preface/013475407 7.pdf.

Wilson, John. 1963. Thinking with Concepts. Cambridge University Press.

Yatham, Lakshmi N., Sidney H. Kennedy, Sagar V. Parikh, Ayal Schaffer, David J. Bond, Benicio N. 
medRxiv preprint doi: https://doi.org/10.1101/2021.11.13.21266303; this version posted November 16, 2021. The copyright holder for this preprint (which was not certified by peer review) is the author/funder, who has granted medRxiv a license to display the preprint in perpetuity.

It is made available under a CC-BY-NC-ND 4.0 International license .

Frey, Verinder Sharma, et al. 2018. "Canadian Network for Mood and Anxiety Treatments (CANMAT) and International Society for Bipolar Disorders (ISBD) 2018 Guidelines for the Management of Patients with Bipolar Disorder." Bipolar Disorders 20 (2): 97-170.

Yildiz, A., M. Nikodem, E. Vieta, C. U. Correll, and R. J. Baldessarini. 2015. "A Network MetaAnalysis on Comparative Efficacy and All-Cause Discontinuation of Antimanic Treatments in Acute Bipolar Mania." Psychological Medicine 45 (2): 299-317.

Zarate, Carlos A., Mauricio Tohen, Michael D. Banov, Michelle K. Weiss, and J. O. Cole. 1995. "Is Clozapine a Mood Stabilizer?" The Journal of Clinical Psychiatry 56 (3): 108-12. 
medRxiv preprint doi: https://doi.org/10.1101/2021.11.13.21266303; this version posted November 16, 2021. The copyright holder for this preprint (which was not certified by peer review) is the author/funder, who has granted medRxiv a license to display the preprint in perpetuity.

It is made available under a CC-BY-NC-ND 4.0 International license .

Table 1 - Evidence synthesis according to network meta analysis

\begin{tabular}{|c|c|c|c|}
\hline \multicolumn{2}{|c|}{$\begin{array}{l}\text { Acute effects according to } \\
\text { (Yildiz et al. 2015) and (Bahji et al. 2020) }\end{array}$} & \multicolumn{2}{|c|}{$\begin{array}{l}\text { Prophylactic effects according to (Miura } \\
\qquad \text { et al. 2014) }\end{array}$} \\
\hline Mania & Depression & Mania & Depression \\
\hline \multicolumn{4}{|c|}{ Superior to placebo: } \\
\hline Lithium & Divalproex & Risperidone Lai & Lamotrigine \\
\hline Quetiapine & Lurasidone & Lithium & Lithium \\
\hline Valproate & Quetiapine & Quetiapine & Quetiapine \\
\hline Risperidone & Cariprazine & Olanzapine & Fluoxetine \\
\hline Olanzapine Cariprazine & Lamotrigine & & \\
\hline Carbamazepine & Olanzapine & & \\
\hline Haloperidol & Tranylcypromine & & \\
\hline Paliperidone & Imipramine & & \\
\hline Aripiprazol Arsenapina & Venlafaxine & & \\
\hline Ziprasidone & Fluoxetine & & \\
\hline \multicolumn{4}{|c|}{ Equivalent to placebo: } \\
\hline Oxcarbazepina & Tranylcypromine & Imipramine & Imipramine \\
\hline Lamotrigine & Imipramine & Paliperidone & Paliperidone \\
\hline Licarbazepine & Venlafaxine & Carbamazepine & Lamotrigine \\
\hline
\end{tabular}


medRxiv preprint doi: https://doi.org/10.1101/2021.11.13.21266303; this version posted November 16, 2021. The copyright holder for this preprint (which was not certified by peer review) is the author/funder, who has granted medRxiv a license to display the preprint in perpetuity.

It is made available under a CC-BY-NC-ND 4.0 International license .

\begin{tabular}{|l|c|c|c|}
\hline Verapamil & Fluoxetine & Risperidone Lai & Carbamazepine \\
& Aripiprazole & Aripiprazole \\
& Olanzapine & \\
\hline
\end{tabular}


medRxiv preprint doi: https://doi.org/10.1101/2021.11.13.21266303; this version posted November 16, 2021. The copyright holder for this preprint (which was not certified by peer review) is the author/funder, who has granted medRxiv a license to display the preprint in perpetuity.

It is made available under a CC-BY-NC-ND 4.0 International license .

Table 2 - Evidence synthesis according to observational studies

\begin{tabular}{|c|c|c|}
\hline $\begin{array}{l}\text { Drugs increasing } \\
\text { odds of rehospitalization, } \\
\text { according to } \\
\text { (Lähteenvuo et al. 2018). }\end{array}$ & $\begin{array}{l}\text { Drugs preventing } \\
\text { hospitalizations for } \\
\text { depressive episodes, } \\
\text { according to } \\
\text { (Joas et al. 2017). }\end{array}$ & $\begin{array}{l}\text { Drugs preventing } \\
\text { hospitalizations for } \\
\text { manic episodes, } \\
\text { according to } \\
\text { (Joas et al. 2017). }\end{array}$ \\
\hline $\begin{array}{l}\text { Antidepressants } \\
\text { Benzodiazepines }\end{array}$ & $\begin{array}{l}\text { Lithium } \\
\text { Valproate } \\
\text { Lamotrigine } \\
\text { Quetiapine } \\
\text { Olanzapine }\end{array}$ & $\begin{array}{l}\text { Lithium } \\
\text { Valproate } \\
\text { Quetiapine } \\
\text { Olanzapine } \\
\text { Carbamazepine }\end{array}$ \\
\hline
\end{tabular}


medRxiv preprint doi: https://doi.org/10.1101/2021.11.13.21266303; this version posted November 16, 2021. The copyright holder for this preprint (which was not certified by peer review) is the author/funder, who has granted medRxiv a license to display the preprint in perpetuity.

It is made available under a CC-BY-NC-ND 4.0 International license .

Figure 1 - The number of publications per year including the term "mood stabilizer" in Medline database.
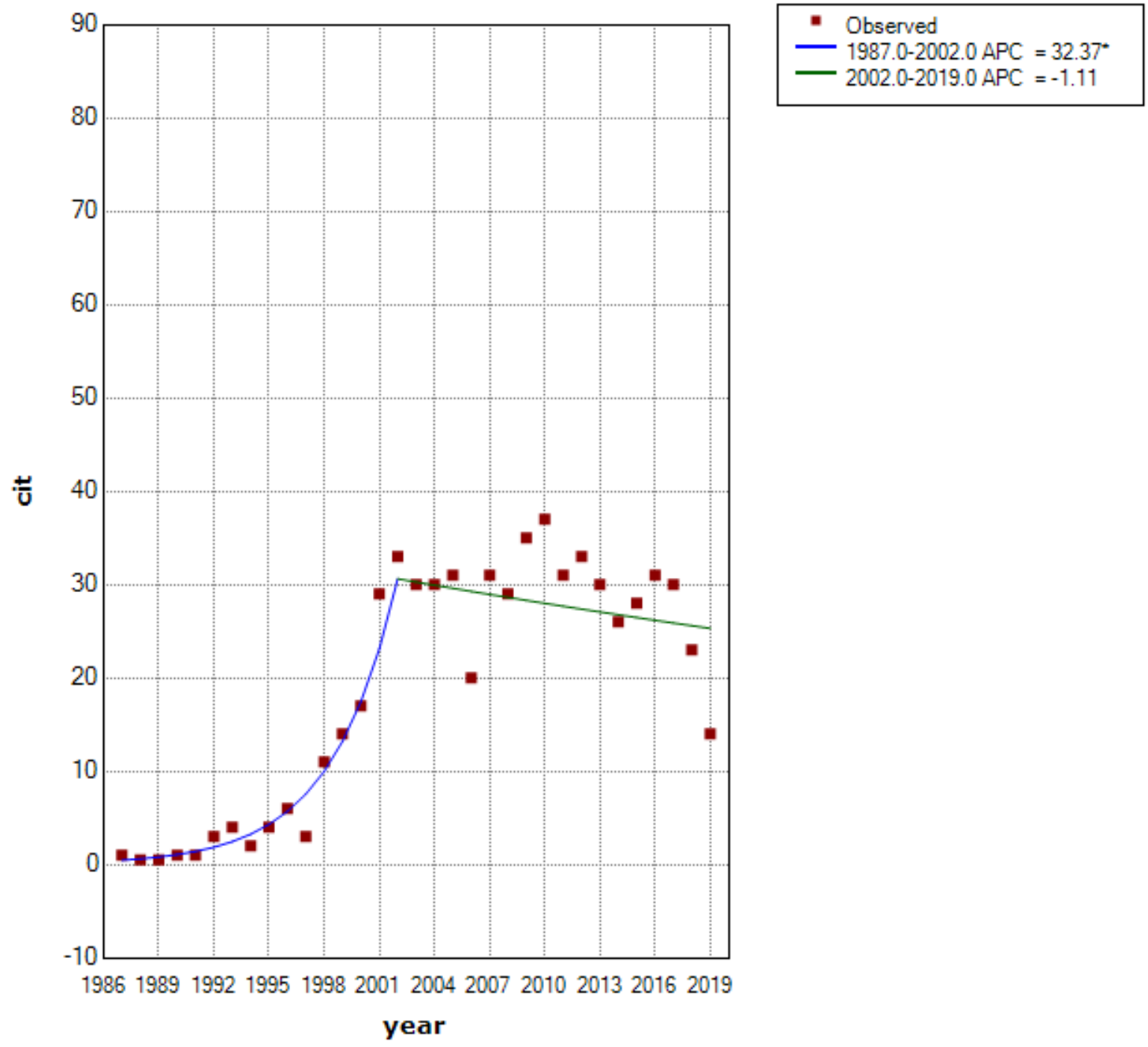

There is one joinpoint indicating that the Annual Percent Change is significantly different from zero at the alpha $=0.05$ level. 
medRxiv preprint doi: https://doi.org/10.1101/2021.11.13.21266303; this version posted November 16, 2021. The copyright holder for this preprint (which was not certified by peer review) is the author/funder, who has granted medRxiv a license to display the preprint in perpetuity.

It is made available under a CC-BY-NC-ND 4.0 International license .

Figure 2 - The number of publications per year including the term "bipolar disorder" in Medline database.
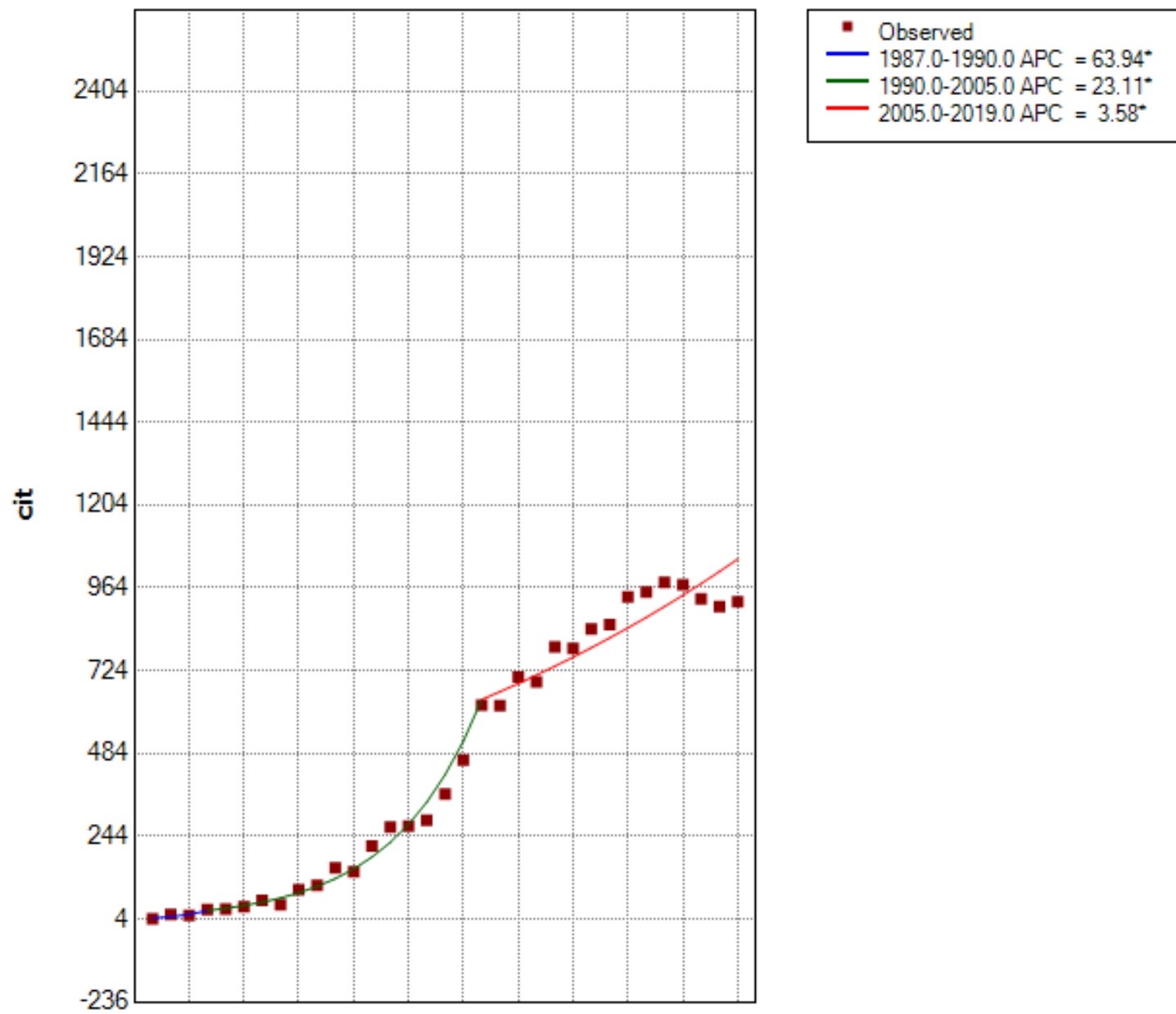

198619891992199519982001200420072010201320162019

year

There are two joinpoints indicating that the Annual Percent Change is significantly different from zero at the alpha $=$ 0.05 level. 
Figure 3 - Timeline of proposed definitions

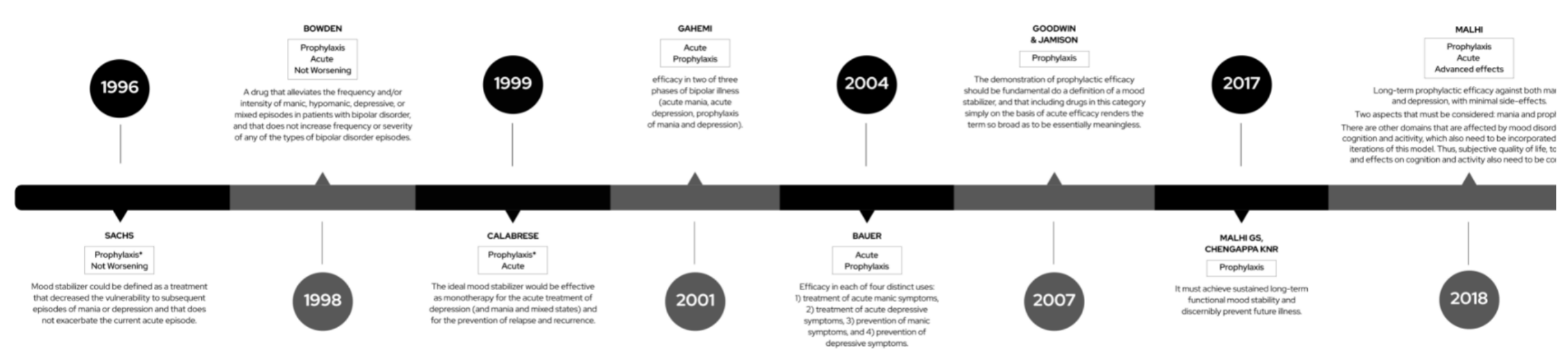


medRxiv preprint doi: https://doi.org/10.1101/2021.11.13.21266303; this version posted November 16, 2021. The copyright holder for this preprint (which was not certified by peer review) is the author/funder, who has granted medRxiv a license to display the preprint in perpetuity.

Figure 4 - Hierarchy of a mood stabilizer: concepts
$\square$ MOOD ESTABILIZER $\square$ NOT A MOOD ESTABILIZER

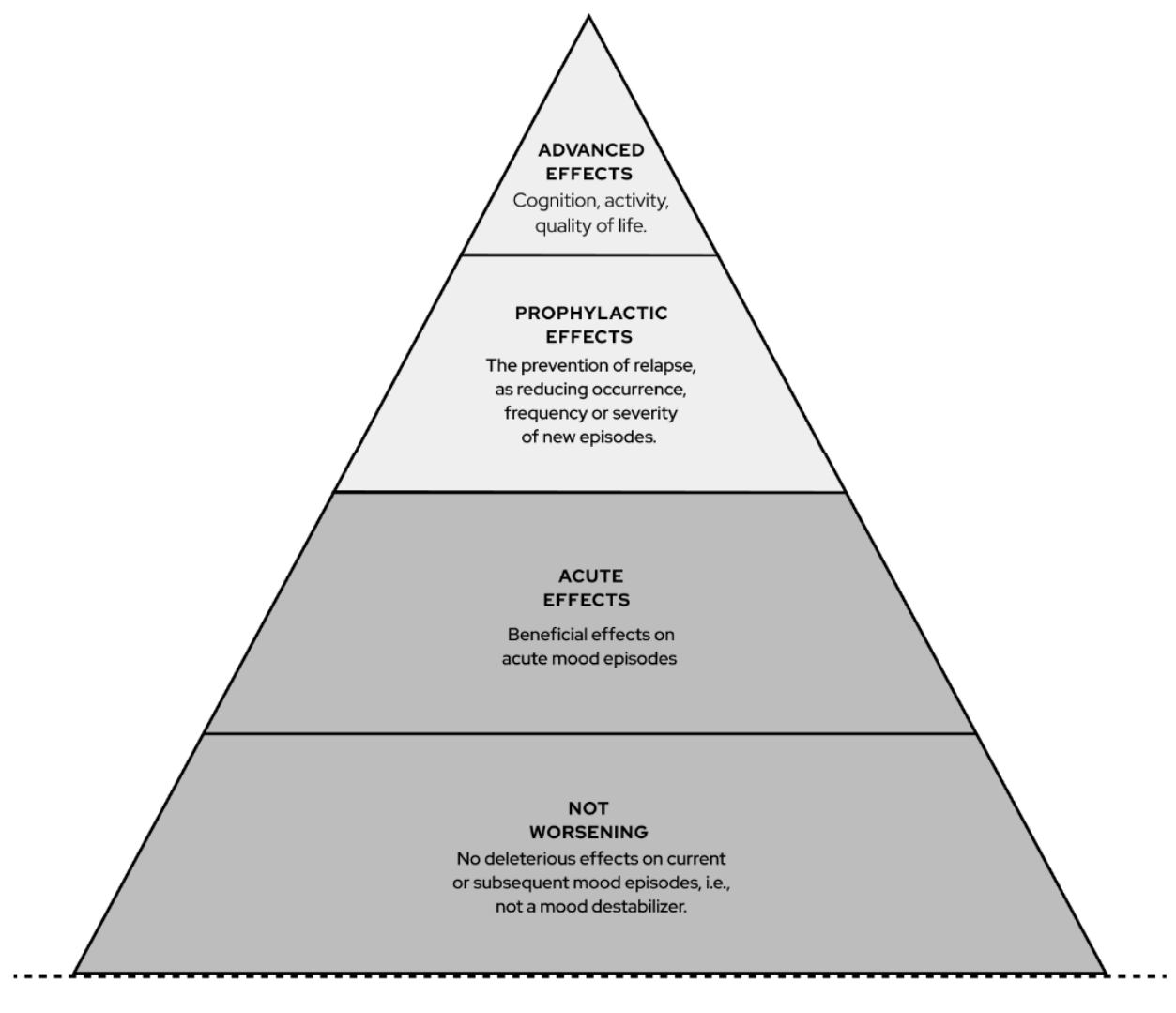

MOOD DESTABILIZERS 
medRxiv preprint doi: https://doi.org/10.1101/2021.11.13.21266303; this version posted November 16, 2021. The copyright holder for this preprint (which was not certified by peer review) is the author/funder, who has granted medRxiv a license to display the preprint in perpetuity.

\section{Figure 5 - Hierarchy of a mood stabilizer: operationalization}

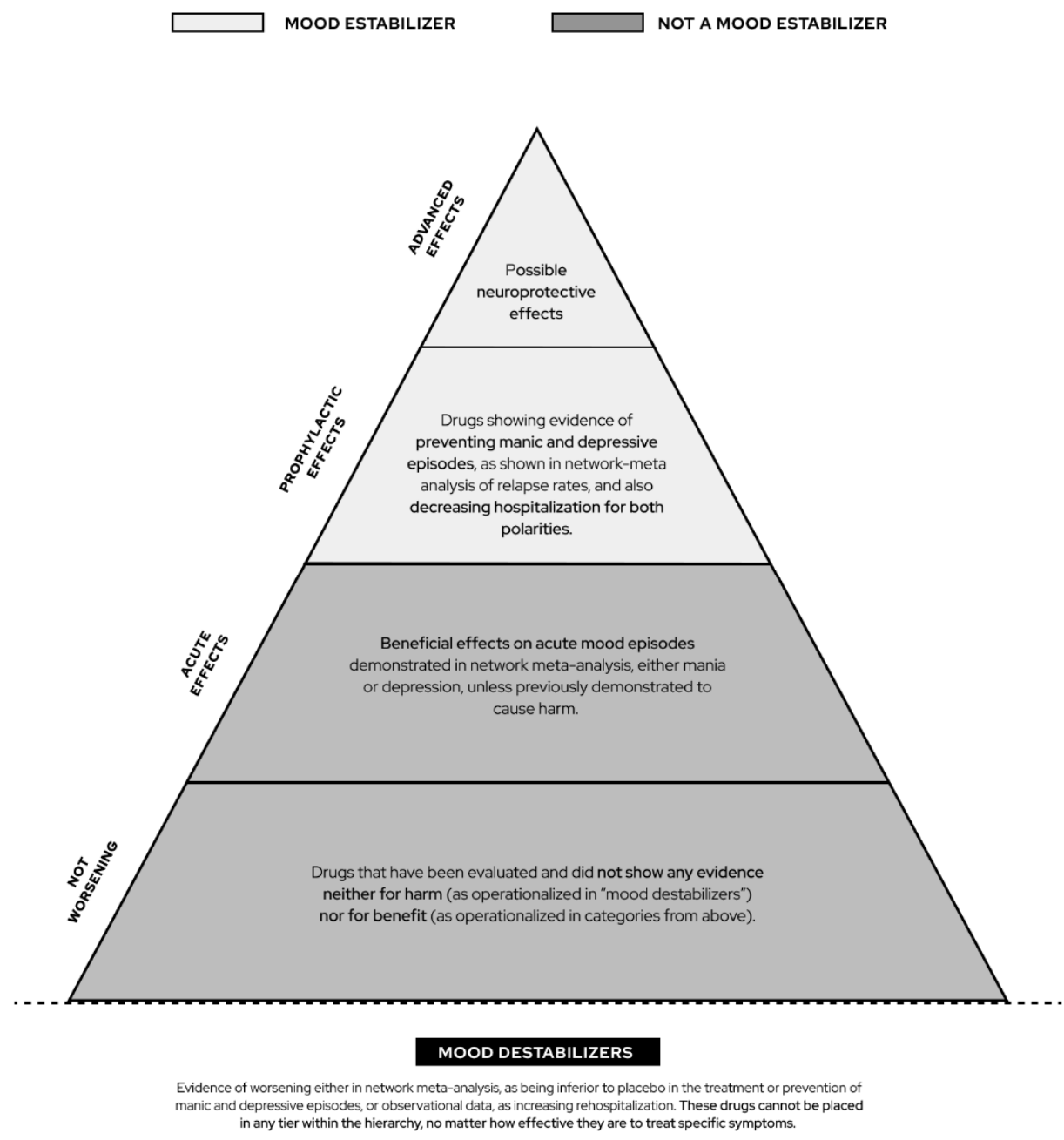


medRxiv preprint doi: https://doi.org/10.1101/2021.11.13.21266303; this version posted November 16, 2021. The copyright holder for this preprint (which was not certified by peer review) is the author/funder, who has granted medRxiv a license to display the preprint in perpetuity.

It is made available under a CC-BY-NC-ND 4.0 International license .

Figure 6 - Hierarchy of a mood stabilizer: drug allocation

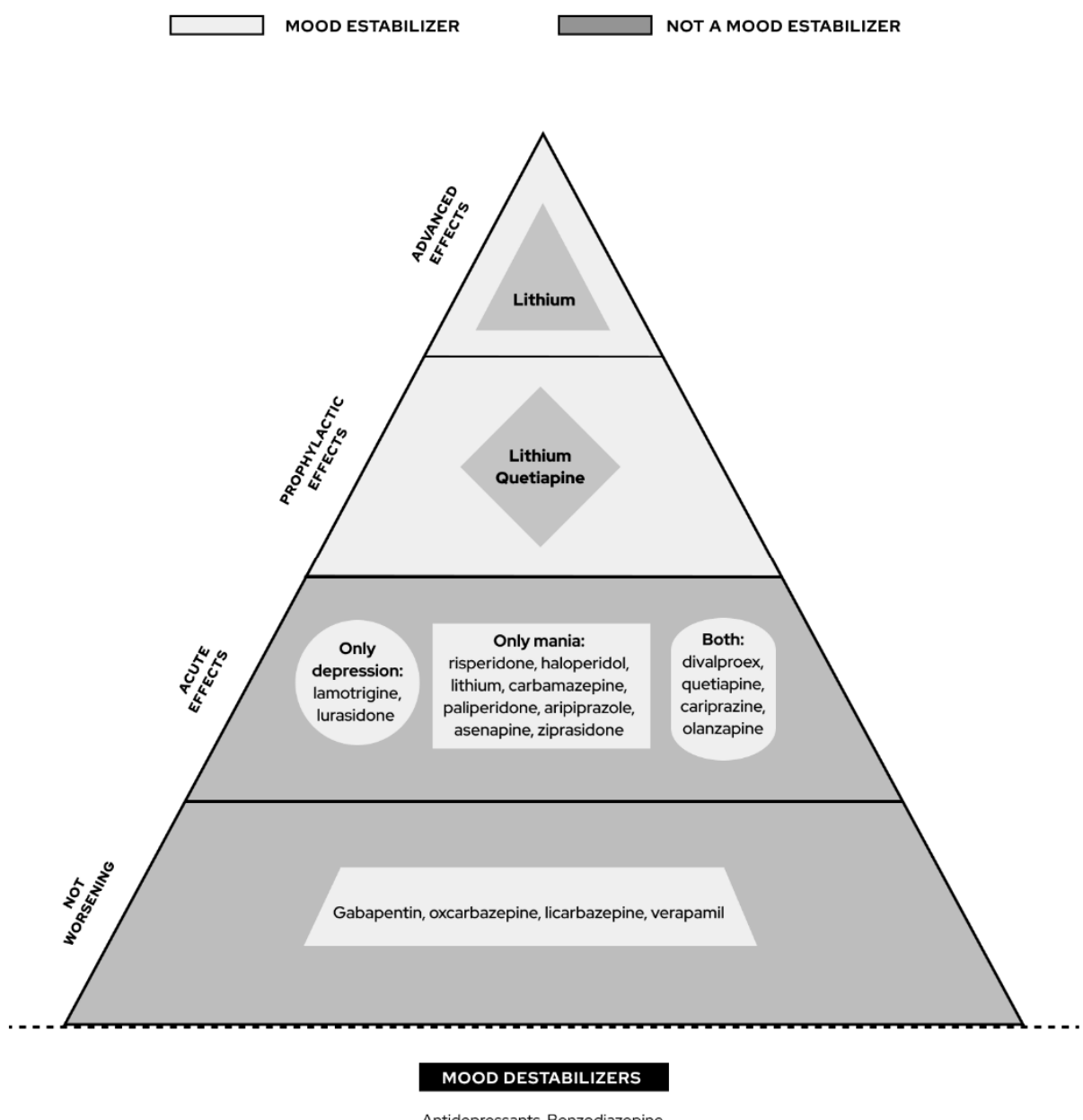

